EGU21-2024

https://doi.org/10.5194/egusphere-egu21-2024

EGU General Assembly 2021

(c) Author(s) 2021. This work is distributed under

the Creative Commons Attribution 4.0 License.

\title{
Natural Gamma-Ray Background Characterization in Pyhasalmi Mine
}

\author{
Vladimir Gostilo ${ }^{1}$, Serhii Pohuliai ${ }^{1}$, Alexander Sokolov ${ }^{1}$, Jari Joutsenvaara ${ }^{2}$, and Julia Puputti ${ }^{2}$ \\ ${ }^{1}$ Baltic Scientific Instruments, Riga, Latvia (office@bsi.Iv) \\ ${ }^{2}$ Kerttu Saalasti Institute, University of Oulu (jari.joutsenvaara@oulu.fi)
}

We present the results of measuring the gamma-ray background performance of Pyhasalmi mine, the deepest one in Europe. Two underground facilities in Lab $2(1440 \mathrm{~m})$ and Lab $5(1410 \mathrm{~m})$ were investigated. Based on measurements made in Lab 2 with a low-background HPGe spectrometer, we determined the integral gamma-ray background count rate in the energy range of $40 \mathrm{keV}$ to 2.7 $\mathrm{MeV}$ to be $0.095 \mathrm{~s}^{-1} \mathrm{~kg}^{-1}$. The minimum detectable activities of some natural and artificial nuclides were less than $0.071 \mathrm{~Bq} / \mathrm{kg}\left({ }^{226} \mathrm{Ra}\right), 0.77 \mathrm{~Bq} / \mathrm{kg}\left({ }^{40} \mathrm{~K}\right)$ and $0.012 \mathrm{~Bq} / \mathrm{kg}\left({ }^{137} \mathrm{Cs}\right)$. The specific activities of natural nuclides in the shotcrete covering the walls of the Lab 2 were higher than those in the rock: $100.3 \mathrm{~Bq} / \mathrm{kg}\left({ }^{232} \mathrm{Th}\right), 161.7 \mathrm{~Bq} / \mathrm{kg}\left({ }^{226} \mathrm{Ra}\right)$ and $1171 \mathrm{~Bq} / \mathrm{kg}\left({ }^{40} \mathrm{~K}\right)$ in the shotcrete covering and $47.6 \mathrm{~Bq} / \mathrm{kg}\left({ }^{232} \mathrm{Th}\right), 83.1 \mathrm{~Bq} / \mathrm{kg}\left({ }^{226} \mathrm{Ra}\right)$ and $1513 \mathrm{~Bq} / \mathrm{kg}\left({ }^{40} \mathrm{~K}\right)$ in the rock. The measurements showed that the gamma-ray background level in Lab 5 is significantly lower than that in Lab 2. The integrated gamma-ray background count rate for the energy range of $40 \mathrm{keV}$ to $2.7 \mathrm{MeV}$ was 0.028 $\mathrm{s}^{-1} \mathrm{~kg}^{-1}$ for Lab 5. Purging the measuring chamber of the gamma spectrometer with nitrogen gas at a rate of $0.15 \mathrm{~L} / \mathrm{h}$ allowed to further improve this parameter to $0.021 \mathrm{~s}^{-1} \mathrm{~kg}^{-1}$. In general, the results of this study confirm that the level and energy spectrum of background gamma radiation in the underground facility within the studied energy range is defined mainly by the composition of the walls of the Labs. 